\title{
ベトナム中部および南部の伝統的木造民家の架構に関する建築史的考察 A STUDY ON THE STRUCTURAL SYSTEM OF TRADITIONAL TIMBER HOUSES IN THE CENTRAL AND SOUTHERN PARTS OF VIET NAM
}

\author{
チャンティクエ ハー*，山田幸正**
}

Thi Que Ha TRAN and Yukimasa YAMADA

\begin{abstract}
'This paper refers to the structural system of traditional. farmers' dwellings in the central and southern parts of Viet Nam from a historical point of view, being based on the surveys since 1998 in the five provinces; Thua Thien Hue, Quang Nam, Quang Ngai, Dong Nai and Tien Giang. At first, the authors discuss the original meanings of terms for structural composition and its members, and then, the architectural features of the connecting details in the part under the ridge by comparison between the center pillar type and the two pillars type. We conclude that both constructional types might derive from indigenous ways maintained from the time before Vietnamese's conquest. A center pillar has remained mainly in the southern part, and a king post has enhanced symbolic meaning in the central part of Viet Nam.
\end{abstract}

Keywords: Southeast Asia, Traditional Farmers'Dwellings, Timber Structure, Structural Terms, Center Pilar, King Post 東南アジア、民家、木構造、構造用語、中柱、束

\section{1. はじめに}

ベトナム全土に遺存する伝統的木造住宅を対象として1997年度よ り㥶施されてきた民家調查は、すでに全国十省において完了し、 4, 284 件の実例についての記録が保存されている。また、それらの調 查結果を踏まえて若干の報告や論考も出されている!。従来、ベトナ ム、とくにその文化については地理的・歴史的に、中国の強い影響 を受けた北部地域、チャンパ文化の中部地域、そしてクメール文化 の南部地域上分けて論じられることが多く、当初、民家の建築的系 統についてもおおむねそうした区分があてはまるものと信じられて いた?。民家における木造架構法をはじめ、その平面構成や敷地配置 においても、北部の民家は中部や南部のそれとは大きく異なってい ることは、表面上の観察からも十分に理解できるところである。し かし、これまで調查された中部や南部の民家には、北部にみられた 17ー18 世紀に遡れるような実例はなく、せいぜい19 世紀後半から 20 世紀前半に属する比較的新しい例ばかりで、民家建築の歴史的変 遷を明らかにすることは容易なことではなかった。そこで本稿では、 中部および南部に遺存する伝統的木造民家について、そ机らの建設 実年代によるのではなく、中部や南部の民家架構の型式やそこに用 いられている部材に対する名称について考察したうえで、斜梁の合 掌部分における接合手法などに着目し、それらをとくに建築技法の 発展過程よして整理することによって、中部および南部の民家の歴
史的な展開過程を類推しようと試みるものである。

本稿において考察対象としたのは、これまでに調査を終えた中部 の三つの省、トウティエンフエ省（以下、「フエ省」と呼ぶ）、クア ンナム省、クアンガイ省と、南部の二つの省、ドンナイ省、ティエ ンザン省、以上合計五つの省の実例である。地元の情報にもとづい てベトナム側が中心に実施した第一次調查における対象事例は、フ エ省 690 件、ドンナイ省 401 件、クアンガイ省 307 件、ティエンザ ン省 350 件、クアンナム省 356 件で、5 省あわせて 2,104 件にも及

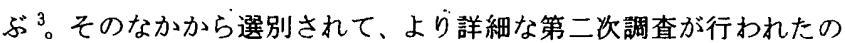
は、フエ省 65 件、クアンナム省 35 件、クアンガイ省 36 件、ドンナ イ省 25 件、ティエンザン省 35 件であった。なお、筆者らもフエ省 で 59 件、クアンナム省で 27 件、クアンガイ省で 3 件、ドンナイ省 で 22 件、ティエンザン省で 25 件の事例については、独自に赛測お よび聞き取りなどの調查を実施した ${ }^{4}$ 。

\section{2.中部と南部における架構型式とその名称}

\section{1 架構型式}

中部から南部にかけて遺存する民家の木造骨組をみると、概して 奥行方向に水平に架かる梁がほとんど使われず、屋根勾配に沿って 斜めに架かる斜梁（kèo）によっておもに構成されている。それらの 斜梁は柱間ごとに渡され、より下方の斜梁がそれより上の材尻に載
* 東京都立大学大学院工学研究科建築学尃攻 博士課程・修士 (学術)

** 東京都立大学大学院工学研究科建築学尃攻 助教授・博士: (管学)
Graduate Student, Tokyo Metropolitan Univ., M.A.

Assoc. Prof., Tokyo Metropolitan Univ., Dr. Eng. 
るものが一般的で、こうした架構（kèo chồng）は中部から南部にか けての民家に共通してみられる特徴のひとつといえよう。ここでは、 図 1 に示したように、大きく二つの型式にまず分けてみることにす る。すなわち、架構の中央に棟木を支持する柱が立つもの（これま

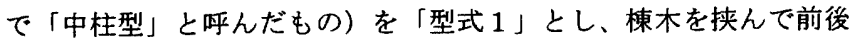
に2本の柱が立つもの（従来「束立ち型」と呼んだ中央に束の立つ ものと、束の立たないものとがあるが、ここではそれらを区別しな

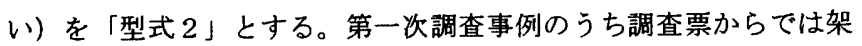
構が判別できない 162 例を除く 1,799 例をみると 5 、各省あわせて 1,426 例々いう大半の事例が型式 2 に属している。一方、型式 1 に属 するものは 373 例で、南部の二つの省だけで計 348 例を数える。

\section{2 聞き取り調査による架構名称}

それぞれの調查において架構に対する名称を聞き取りし、それを 各省ごとに一覧化したものが表 1 である ${ }^{6}$ 。vì kèoは「架構」、nhàは「家、 建物」をそれぞれ表わす語裹であり、その後に続く語裹が架構型式を 表わすと思われるので、以下は vi kèo nhàを省略して呼ぶ。形式 1 の 架棈に関する呼称はフエ省で rọi、クアンナム省で xuyên tâm、ドン ナイ省およびティエンザン省の南部 2 省で nọc ngự とそれぞれの地 域で異なっている。また、型式 2 についても、フェ省では rường、ク アンナム省では n̛ờng と đâm trính の二つの呼称が存在し、南部 2 省 では xuyên trính と呼ばれている。ベトナム語の語意からすると、đâm とは「刺す」、xuyên とは「貫通する」という意味をもつことから、 これらの đâm と xuyên はほぼ同じような意味合いで使われているも のと考えられる。したがって、型式 2 についての呼称はフエ省と クアンナム省では nường、クアンナム省と南部 2 省では xuyên trinh（または đâm trinh）という二うの言葉に集約できる。

なお、調査から得た民家の木造架構に関するこれらの名称は、既 往文献に述べられているものとほぼ一致するものであるが 、クアン ビンからフエの中部でも北側地域でみられる民家について、Pierre Gourou は nhà rương という名称を用いている8 。前述した聞き取り調 查による名称に加えて、以下、この語裹も含めて検討したい。

\section{3. 架構名称に用いられている語寨の意味}

架構の型式などに用いられている語魚の意味について、以下に挙 げる辞書・文献にもとづいて考察を進めた。文献 (1):1651 年にポ ルトガルの宣教師Al exandre De Rhodesによって作成されたもので、 安南語をポルトガル語およびラテン語で対訳した辞書。ベトナム語 がローマ字表記された最初の辞書として知られる。文献 (2): 南部 の語裹に関するベトナム語辞書。文献 $(3)$ : 中部クアンビン・クア ンチ・トウティエンフエの方言に関する文献。文献 $(4)$ : ベトナム の古語というべき喃字に関する辞書。文献 $(5)$ : ベトナム語の現代 国語辞典。

3.1 型式 1 に対する語葲 rọi、xuyên tâm、nọc ngựa

型式 1 の架構に対してフエ省で使われている rọi という語は、本来 「照らす」という意味をもつとされ9、この語が建築の架構よどのよ うに関保寸るのかはよくわからない。また、クアンナム省で使われ ている xuyên tâm 上南部 2 省で使われている nọc ngựaについて、い
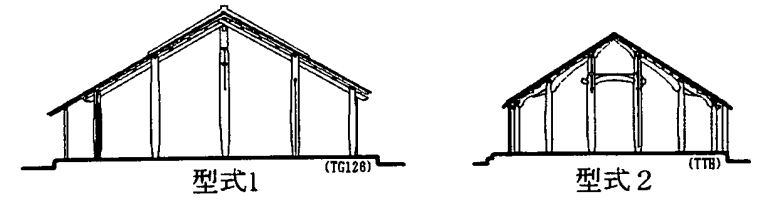

图1：架構型式（）内調植番丹、また図の蛨尺は镜一してある

\section{表 1: 架構名称}
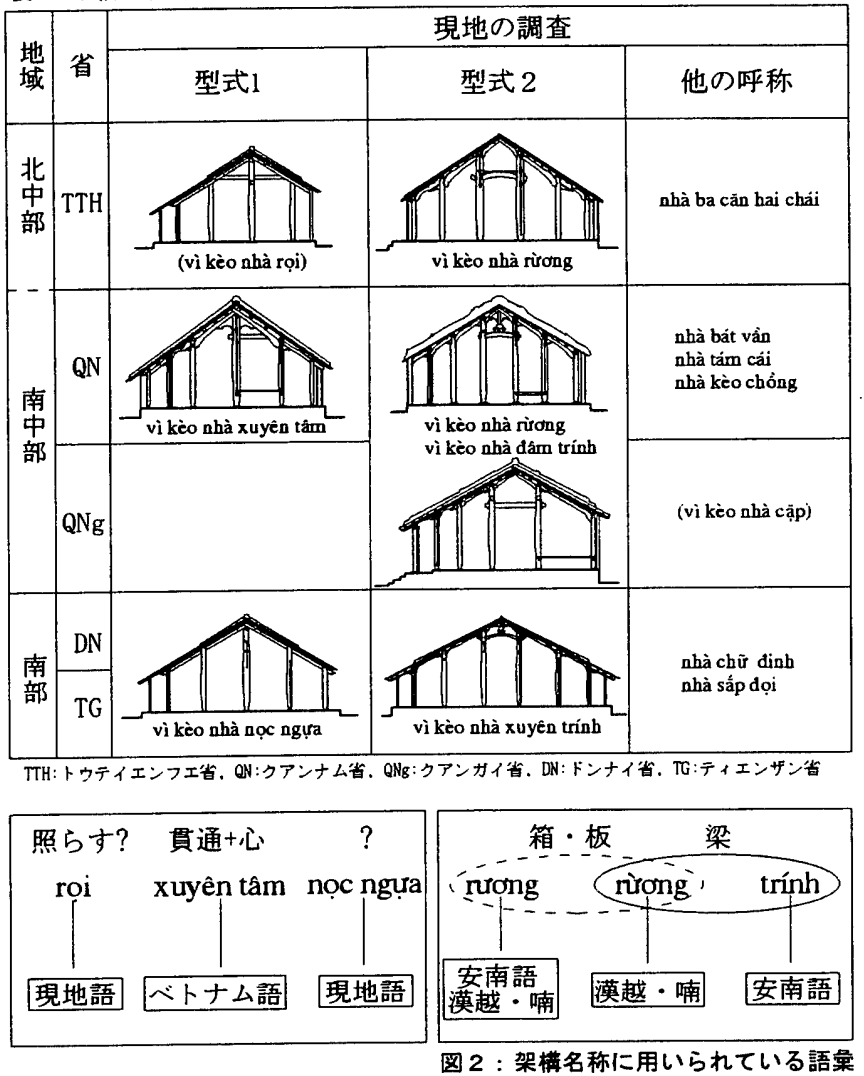

ずれの辞書や文献でもそれらに該当する語彙の解説は見いだすこと ができなかった。しかし、前者を直訳すると「中心を貫通する」と なることから、おそらく中心に立つ柱とその架構を表見しているも のと考えられる。現時点では、 rọi も nọc ngựa も、架構の形や状態に 直接関わる意味をもつかどうかは不明であるが、少なくとも、これ らの語彙が現代ベトナム語として一般的に使われているものではな く、おそらくは中部から南部にかけての地域で古くから土着にあっ た語彙である可能性が高い(図 $2 \cdot$ 左)。

\section{2 型式 2 に対する語象 rương、rường、trinh}

形式 2 の架構に対する語彙のうち、trính とは文献 (1)によれば、 「家屋において奥行方向の梁」を表わすとされ10、喃字には書き直 せない語であり、また現代ベトナム国語辞典にも trính という語裹は ない。一方、文献 $(1)$ には揭載されていない rường という語彙は、 喃字で「樑」及び「木」と「床」の字から組み合わせで表わすこと ができ ${ }^{11}$ 、現代語としても「家屋の上部構造に使い、束あるいは斗 を受ける小さな梁」という意味で用いられている ${ }^{12}$ 。 rường 上 trính の二つの語彙はともに「梁」の意味を含むものと考えられるが、rường が喃字において意味をもつ漢字で表現できることから、なんらかの 中国からの影響が想像され、一方、trính という語は、おそらく安南 語、つまり中部・南部にあった土着の言葉に由来するものであろう。 
また、rường なる語が喃字において「木十床」という漢字の組み合わ せで書かれることに注目すれば、木製の「床」を含意する語である 可能性が考えられる。さらにいまひとつ、Piere Gourou が用いた rương という語裹であるが、これは文献（1）において「屋根の近く に配される木材の板」13、また喃字では「箱」という漢字を含んでお り ${ }^{14}$ 、現代ベトナム国語辞典でも「収納するための箱」15 という解説 がみられる。このようなことを踏まえるならば、rương、rường、trính という三つの語彙には図 2右側に示すような関倸が考えられる。

少なくとも、安南語がポルトガル語で翻訳された 17 世紀中頃にお いて、すでに「梁」を意味する rương と trính という語で呼ばれた架構 が存在していたと考えられる。一方、rường という言葉は中国の漢字 を使い、明らかに中国からの直接的な影響が考えられ、そうしたこ とから、おそらく19世紀初にフエに成立した阮朝を中心にこうした 呼称が広がったのではないかと想像される。また、これらの語裹と は対照的に、さきの型式 1 の架構が辞書や文献などではほとんど紹 介されておらず、型式 1 の架構が、言語的に正統的でない、どちら かといえば民間に流通した語裹で呼ばれていたことは注目される。 その一方で、型式 2 の架構は「ある正統性」をもったものと位置づ けられていたよ考えられる。

\section{4. 架構型式 1 の建築技法的な特徽}

\section{1 現存実例による中部と南部との比較}

第一次調查において型式 1 として報告された例は、フエ省で11 例、 クアンナム省で 14 例だけであった。それに対して、ドンナイ省とテ イエンザン省の南部 2 省ではそれぞれ 180 例と 168 例で、比較的に 多くの事例が報告され、型式 2 の報告例とほほ同じ割合となってい る ${ }^{16}$ 。ここのように、型式 1 の架構は、中部では比較的珍しいもので、 南部においては一般的に普及したものであると言えよう。また、中 部で型式 1 の架構をもうた民家が間口 3 間と小規模であるのに対し て、南部 2 省でみられた型式 1 の架構をもった民家はすべて間口 5 間の家屋ばかりで、その規模は間口・奥行とも $13 \mathrm{~m}$ あまり大きい (平均値間口 $13.071 \mathrm{~m} \times$ 奥行 $12.992 \mathrm{~m}$ ) ${ }^{17}$ 。

構造的にみる上、フェ省における型式 1 の事例では、2枚の板で 合せ梁としたものや竹材を斜梁に用いるものがあり、これらの斜梁 が柱の頂部を挟み、中柱を貫通した水平部材で前後の斜梁と䡔ぐも のが多くみられた（図 3 ・左、表 2 ・(1)）。同じく中部のクアンナム 省の例では、斜梁を柱間 1 間ずつに架け渡し、水平部材は中柱と後 方の斜梁上を繁いでいる（図 3・中、表 2 - (2)）。一方、南部 2 省に みられる例では、水平部材は用いられず、斜梁は中柱およびその前 後の柱の頂部でそれぞれ落とし込まれ、二間分の柱間が連結されて いる(348 例中 163 例 ${ }^{18}$ ) (図 3 ・右、表 2 - (3)上(5)。

斜梁の合掌部分における納まりに注目し、おもな 6 種の手法に整 理した（表 2)19。フエ省ではおもに表 2 の1の手法がみられた。こ こでは柱が直接合掌を受けるのではなく、短い円形の横木を中柱の 頂上に置き、その上に前後の斜梁を載せている。このような手法は、 精巧な切り込みや仕口をもたない、竹組みなど最も初歩的な技法を 映しているもの上思われる。同じく中部クアンナム省の14 例すべて
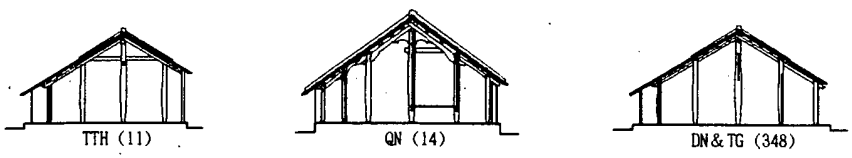

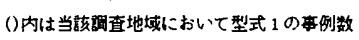

図3: 中部と南部における型式 1 の特徽
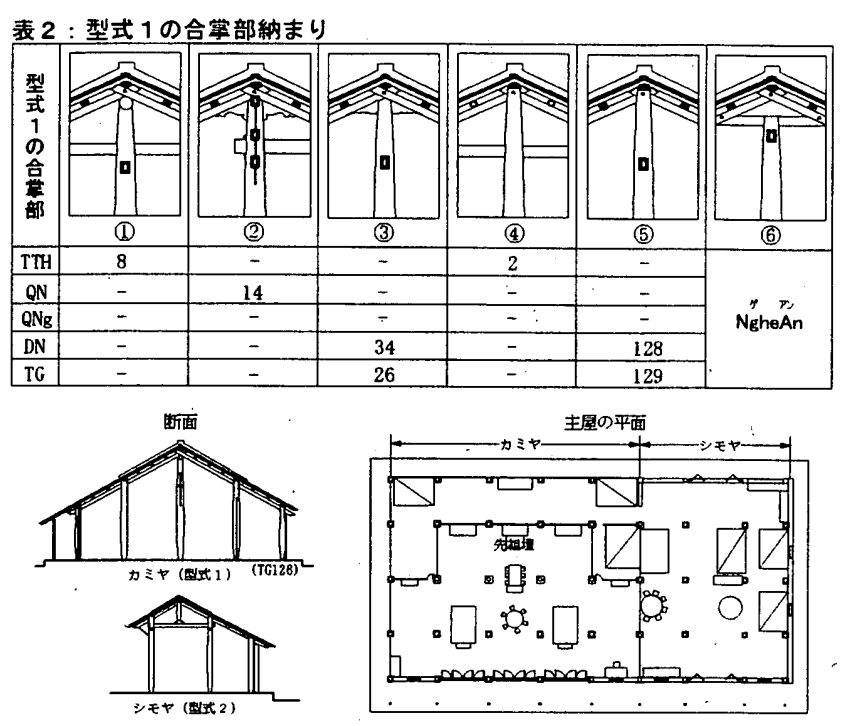

図4: 南部民家の主屋（カミヤとシモヤを連棟する）

で、表 2 の(2)の手法がとられていた。すなわち：中柱は合掌まで到

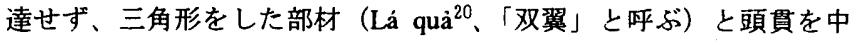
柱の頂部に落とし込み、前述したフエ省での手法よりかなり強固に 固められている。一方、南部2 省では、中部とは異なり、表 2 の(3) および(5)の手法、なかでも(5)がほとんどであった。上述したように、 南部 2 省で形式 1 の架構をもった事例はいずれも大規模であるにも かかわらず、斜梁は柱間 2 間分に架け渡されている場合が多い。斜 梁を中柱の頂部に落とし込み、双翼を省略する場合も少なくない。

中部における型式 1 の架構はそれによって組み立てられる建物の 規模が小さく、技法的にも精巧な造作を要しない、たとえば竹組み の手法にも通じるような、初歩的な段階を示しているのに対して、 南部における型式 1 の架構は大規模に組まれるるだけでなく、部材の 省略なよ゙、技術的に進化した段階のものであることがわかる。

\section{4:2 南部の事例にみる型式 1 の伝統性と变化}

南部民家のひとつの特徴として、主屋が軒を接してたつ格式の異 なる複数の建物から成ることが挙げられる（2 棟を連棟する場合が 多く、それぞれの家屋を「カミヤ」「シモヤ」 ${ }^{21}$ 上呼ぶ)。南部 2 省に おいて詳細な実測調查を行なうことのできた型式 1 の実例 18 例のう ち、カミヤとシモヤがともに現存するものは11例あった。カミヤと シモヤの両棟におけて同じ架構型式が用いられているものは、上述 の 11 例中、たったの 1 例しかなかった。カミヤにおいて型式 1 の架 構が用いられてていても、シ壬ヤでは同じ型式が採用されず、型式 2 の架構、つまり、棟木を挟んで前後に 2 本の柱が立ち、それらの上 部を胴差で連結し、その中央に合掌を支持する束を立てる（図 4 ・ 左)。カミヤ、シモヤ上も入母屋の屋根がかかり、棟の方向は互いに 直交するように、つまり、カミヤを平入りに、シモヤを妻入りに建 てる。台所や食事など日常的な生活空間となるシモヤにおいては、 中央に柱の立つ架構は好まれなかったことは注目すべきことであう 
う。また、10 例中 5 例はシモヤの架構において中央間とその左右間 の差は $100 \mathrm{~mm} \sim 200 \mathrm{~mm} 、 4$ 例は $400 \mathrm{~mm} \sim 700 \mathrm{~mm}$ 程度である。中央の柱間 を左右間の二倍程度にとる例さえあった ${ }^{22}$ 。このように、先祖を祀 るカミヤは格式ある建物として伝統的な形式が維持されることが求 められる一方、日常の生活空間となるシモヤは、利便性など新奇な 形式を取り入れやすかったと想像される（図 $4 \cdot$ 右）。

\section{5. 架構型式 2 の建築技法的な特徽}

棟木を挟んでその前後に柱の立つ型式 2 の架構が中部から南部に かけての諸地域に一般的に用いられていたことは、これまでの調查 結果が如実に示している。家屋中央の柱間上部を慗いでいる胴差の 上側に注目すると、その中央に束を立てるものと束を立てないもの とに二分することができ、さらに後者には胴差の上に厚い板材が張 られる場合がある（図 5 )。

\section{1 東立ちの事例にみる合革部の納まり}

まず、胴差の中央に束が立つ事例について検討してみよう。合掌 部における束や斜梁などの納まりに着目して整理すると、表 3 の左 側 3 列に示すように大別することができる。

〈1〉束が斜梁交差部まで達し、束の上端部に三角形の双翼を落と し込み、その上に斜梁が載るもの

〈2〉束の上端部に落上し込まれた左右の斜梁が、そこで合掌を形 成するもの

〈3〉束が斜梁交差部まで到達せず、束の頂部で横材を介して左右 の斜梁を繫ぐもの

フエ省でみられた束立ち 54 例中 47 例が上述の納まり〈3〉に属 している。なお、フエ省で束の立つ例の大半は、聞き取りの結果、 もともと跼堂として建設されたものであった(54 例中 50 例)。また、 クアンナム省でみられる束立ち 124 例は、すべで納まり〈1〉であ り、クアンガイ省では 125 例中 102 例が〈1〉、23 例が〈3〉の納ま りとなっていた。南部 2 省でみられる束立ちのものは、〈1〉〈2〉

〈3〉のいずれかの納まりで処理されている。そのなかでも、事例 数からみると納まり〈1〉功最も一般的であったといえる。こうし た架構を組み上げていく場合、〈1〉の納まりでは柱に胴差を組んだ 後、束を立て、その頂部に双翼を落とし込み、その上に左右の斜梁 を組むことになる。一方、〈3〉の納まりでは束が斜梁まで到達して いないため、斜梁を先に組んでから、後から束と横材を挿入するこ とができる。このように、納まり〈1〉において束は久かせない部 材であるのに対して、納まり〈3〉では束は付加的な部材として极 われている。言い換えると、〈1〉における束は合掌を支持する構造 的な役割を果たしているのに対して、〈3〉の束には構造的な役割は なく、一種の「飾り」にすぎない。さらに先に述べたように、フエ 省で納まり〈3〉を用いる例はそのほ上んよ゙がもと柌堂であったこ とや、同じ納まりがフエ王宮内にたつ建物にもみられることは注目 に值しよう 23 。納まり〈3〉を用いた場合、中央柱間に束が立つこ とは構造的なことより装飾的、象徵的な意味合いがあったと考えら れる。クアンナム省やクアンガイ省でみられた束は、納まり〈1〉 を用いるものが多いこ上はさきほど述べたが、それらの斗・束・双
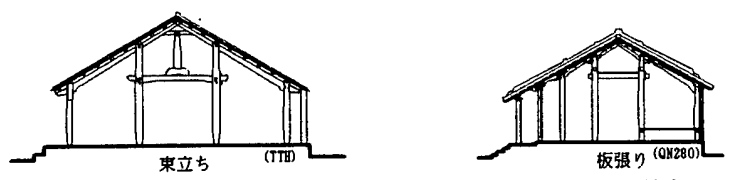

図5：型式 2 の類型

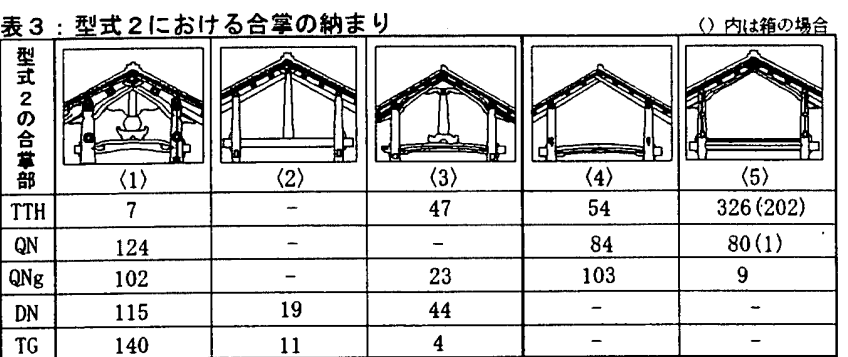

表 4 : 合掌部の納まりと斜梁型式の相関

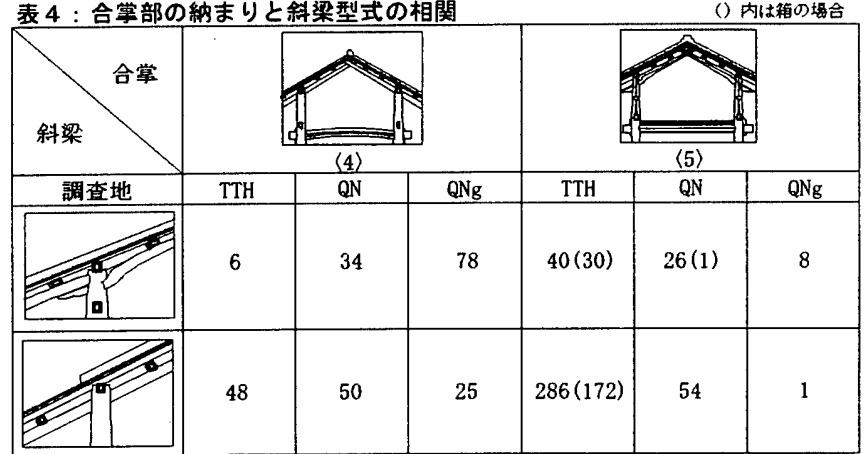

翼などにはその表面に手を込んだ豊かな彫刻が施されるものが多く、 かなり装飾的の印象をうける。構造的な役割をもった束を使いなが ら、それを彫刻などで装飾化しようとしている。また、納まり〈2〉 は一次調査において南部にしかみられない。カミヤとシモヤがとも に現存する第二次調査の事例をみると、カミヤには納まり〈1〉、シ モヤには納まり〈2〉を用いる場合がある。また、南部 2 省の民家 の空間構成をみると、先祖壇が 2 本の正柱列の間に置かれ、ある意 味、最も精神的に重要な空間の上方に束が立てられたと考えられる。 なお、同様な先祖壇の配置と空間構成はフエ省でも少数例みられる。 南部 2 省の例では、家屋の規模が中部のものより大きく高くなって いるにもかかすらず、胴差の位置はむしろ柱のより上方に位置する 傾向がみられ、束はさらに短くなり、実用性が薄れていることが見 てとれる。

\section{2 板張りの事例にみる「床」「箱」}

つぎに、合掌部において束を立てない事例について、表 3 の右側 2 列のようにわけることができる。

〈4〉2本の柱上方を粲ぐ胴差と斜梁によって、中央柱間の上部に 山形五角形の骨組みが形成されるもの

〈5〉同様の骨組みが形成され、胴差の上に厚さ $20 \mathrm{~mm}$ 程度の板材が 張られているもの。ちなみに、前述の束が立つもので胴差の上にこ うした厚板が張られる例はみられない24。

これら〈4〉〈5〉のような合掌部の納まりは、南部の 2 省ではこ れまで 1 例も報告されていない。フエ省では束を立てず、胴差の上 に厚板を張る〈5〉の例が圧倒的に多いことがわかる。クアンナム 省、クアンガイ省と南に行くほど、その比率は下がり、ついには、 
南部のドンナイ省・ティエンザン省ではみられなくなるのである。 これら板張りがフエ省を中心に限定的にあることは極めて興味深い。 それらのなかには，前後の柱位置で胴差より上の部分を横羽目の板 で塞ぎ、家屋中央部に断面が山形五角形をした、まるで閉鎖的な「箱」 のように区画されるものがある。その大半は、これまでの調查によ れば、フエ省に限定的にみられる（202 例、表 3)。クアンナム省で もわずか 1 例であるが、このような箱状の例をみることができた。 閏き取りによる上、この板張り部分は日常使わないものを置く場所 であり、洪水の際の一時的な非難の場所となると言う25。'また、フ エ省での調査において、主屋脇にあって、台所や倉庫となるココヤ Nhà ngang 内に、地上 $1 \mathrm{~m}$ あまりに高床を張り、横羽目の板壁で囲わ れた造り付けの穀物倉庫がみられ、主屋の中央上部、棟近くに設け られた「箱」状の空間との染い関連が考えられる ${ }^{26}$ 。

中部から南部における民家では、水平な梁はほとんど用いず、屋 根に沿って斜梁が柱間 1 間ごとに架かるか、棟から 1 本の長い部材

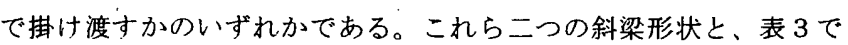
示した合掌部の納まり〈4〉〈5〉との相関を各省ごとにみたものが 表 4である。フエ省とクアンナム省では 1 本の長い斜梁が用いら机 ることが多く、クアンガイ省では逆に柱間ごとに架ける斜梁が使わ れる傾向が読み取れるが、合掌部における 2 種の納まりとの強い相 関関係はみられない。ただ、フエ省において板張りの 326 例中 286 例で、柱間 2 間分架かる長い斜梁が用いられていることは注目され よう。まるで太い垂木のような斜梁は、上述の「床」あるいは「箱」 のような板張り上何らかの関連を示すものかもしれない。

\section{6. まとめ}

以上のように、ベトナムの中部から南部にかけての五つの省で実 施した民家調查の成果を踏まえ、そこにみられる木造架構について、
その言語的な意味をたどったうえで、合掌部の納まりなど建築技法 的な特徽を整理してぎた。これまでの考察結果は以下のように要約 することができる。

（1）棟木を支承する柱を用いる架構型式（型式 1）を表わす rọi や nọc ngựa という語裹は、おそらくこれらの語が示寸架櫵とともに、 越族がこれらの地域に南下する以前から現在のベトナムの中部から 南部にかけての地域で使われていた土着のものが受け継がれたもの であろうと想像される。「棟持ちの柱」が掘立て柱を起源とすること は広く信じられていることであるが、上述のように考えることはこ の説を補強寸るものとなろう。

(2) 型式1の合掌部における納まりから判断すると、柱の頂部に 短い円形の横木を置き、その上で前後の斜梁を組むものが、精巧な 切り込みや仕口をもたない最も初歩的な形を継承する手法である上 思われる。それが次第に、斜梁交差部まで達しない柱はその頂部を 欠き込んで、三角形をした部材を落とし込み、さらにそこに斜梁交 差部自体を落とし込むようになる。柱の頂部を欠き込み、梁などを 輪䓡ぎ込む手法は、北部の民家などでもみられるベトナムの木造建 築を最も特街づけることで、そうした技法が次第に中部から南部に 伝わったことを裹付けていると考えられる。こうした技法が南部に 広がると同時に、家屋は次第に大規模化したのである。

（3）南部の民家では、型式 1 の架構は格式の高い主屋力ミヤにお いて継承されるが、それと軒を接して並び、日常的な生活の場とな るシモヤでは実用性などから次第に束に代えることによって中央の 柱を省くようになる。

（4）2本の柱を胴差で慗ぎ、その上で合掌を組む架構型式（型式 2）を表わす rương、rường、trinh という語裹は、少なくとも 17 世 紀中頃には使われていたもので、rưong と rương はともに中国の漢字 を取り入れた暔字であり、trính は南部地域でかつて使われていた安

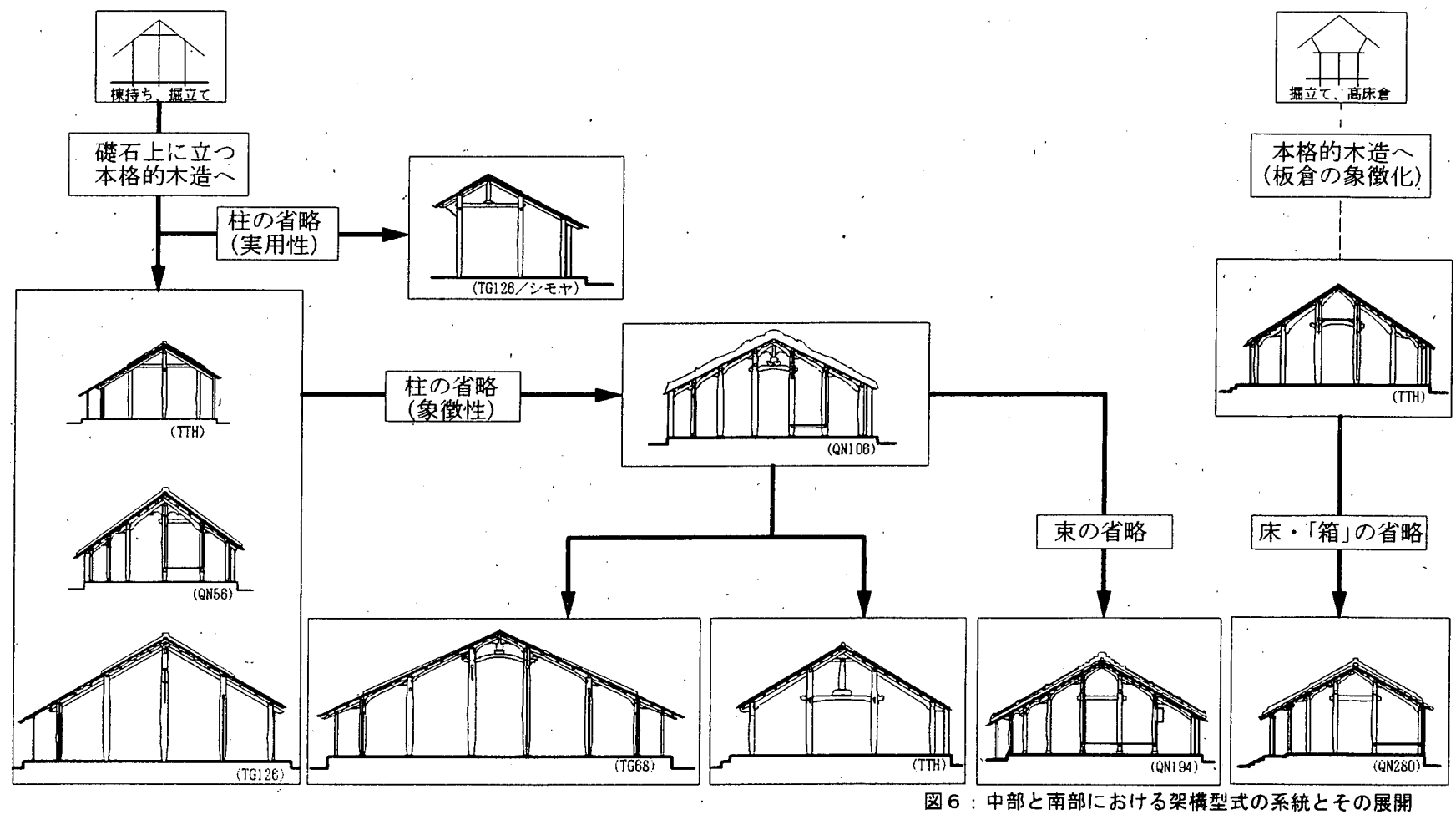


南語に由来する。いずれもすでに土着にあった架樥を南下してきた 越族が樌極的に取り入れた技法・様式であったと推測される。

（5）型式 2 のうち、とくに束のたつ手法は、前述のシモヤにおけ る実用性とはまったく異なる理由により、土着にあった型式 1 から 変化発展してきたのではないかと想像している。原則的に型式 1 上 ほぼ同様、束の頂部を欠き込んで斜梁の交差部まで落上し込むよう になり、さらには合掌に組んだ斜梁の下から差し入れる装飾的な束 に変化していくと想定している。このように実用性の薄れた束は、 建物の中央にたつことにその存在の意味がおかれ、王宮の建物や先 祖を祀る祠堂などで、象徵性を際立たせるための装置となっていく とともに、とくに南部においては型式 1 と同様、家屋自体は大規模 化していく。

（6）Piere Gourou がフェより北の地域の民家として報告した rưong という語裹は「箱」を意味し、型式 2 のうち、とくにフエ省の民家 にみられる床もしくは箱状の厚板張りのものとの密接な関連が指摘 できよう。さらに言えば、東南アジア、南シナ海・東シナ海などに 広くみることができる高床の板倉との関連を連想される。

以上のような内容を図解したものが図 6 である。

\section{奉考文献}

(1) Alexandre De Rhodes:Dictionarium Annamiticum Lusi tanum et Latinum, Romae Typis \& fumptius eipfdem Sacr, Congreg, 1651

(2) Vương Hòng Sèn: Tự vi tiếng viêtı miến nam, NXB Vān hoá, 1993

(3) Võ Xuân Trang: Phương Ngữ Bình Trị Thiên, NXB Khoa học Xã Hội, 1997

(4) Vũ Vàn Kinh: Đại ừ điển chữ nốm, NXBVān nghệ TP.HCM \& Trung tâm nghiên cứu Quốc Hoc, 2002

(5) Viện ngốn ngữ học: Từ diển tiéng việt, NXB Đà nẫng\& Trung tâm từ diển học, 1998

(6) Pierre Gourou: Esqui sse D' une étude de L' habitation Annamite-Dans L'Annam septentrional et Central du Thanh Hoa au Binh Dinh, Pari, 1936 (7) Louis Bezacier: L' art VietNamien, Pari, 1954

(8) Nguyễn Khắc Tụng: Traditional Dwelling-Houses of VietNamese ethnic Groups, Hồi khoa hoc lich sử Viêt Nam, 1994

(9) 昭和女子大学国際文化研究所紀要：べトナム伝続的住居の保存々再生, Vol5, 1999

(10) 昭和女子大学国際文化研究所紀要 : ベトナム伝統住居の体系的研究一 所在調查と意匠技術の編年, Vol7, 2001

（11）若林弘子：高床式建物の源流，弘文堂，1986.7

（12）土本俊和：中近世都市形熊史踚，中央公論美術出版，2003.2

(13) 浅川泣男：住まいの民族建策学，建築資料研究社，1994.6 注

1 ベトナム全国を対象とした伝統的民家の実態調查は、平成 $9 \sim 10$ 年度文部 省科学研究補助金・国際学術研究「ベトナ人伝統住居の保存と再生に関する研 究」(代表 : 平井 聖)、同平成 $11-13$ 年度「べトナム伝統的住居の体系的研 究一所在調查と意匠技法 $の$ 編年! (代表: 友田博通)、同平成 14 年度日本私立 学校振興・学術研究振興資金「ベトナム伝統住居の体亲的研究一文化財保存の国 祭協力」(代表：友田博通) のもとで実施された。

ベトナム北部における伝絰的木造民家の架橎型式や空間構成にみら九る建 策史的特街などについては、すでに別の拙稿において踰した。「ベトナム北部・ バクニン省及びナムディン省の伝統的民家架構形式に関する研究」日本建筑学 会計画系踰文集第 550 号 pp.267-2732001 年 12 月。「ベト十ム北部 4 省の 伝統的民家主屋における空間梅成」 日本建筑学会計画系踚文集第 579 号 pp. $135-1402004$ 年 05 月。

2 ベトナム民家を初めて研究したことで知られるフランス人Pierre Gourou (文获 6 ) はフランスの保護地域の北部トンキンと中部安南 (タインホアから ビンデンまで）を別して踚じ、また、アメリカとの戦争後において伝統的 民家を研究した先人的存在である Nguyênn Kbắc Tung (文献 8) は北部・中部· 南部にそれぞれ歴史上の地理的・行政的な区分したうえで民家を紹介している。 Nguyến Kháa Tụng の研究とその以降のべトナム研究者とも、Pierre Gourou の 研究から影響を多く受けたものである。

3 当晐の民家調查は、1998 年度にフエ省とドンナイ省、2000 年度にクアン ガイ省とティエンザン省、さらに2001年度にはクアンナム省でそれぞれ実施 された。ベトナム㑡による調查は、各省の文化情報省保存博物館局の協力のも と、建設省建筑研究所、フエ大学建策学科、ホーチミン建策大学が中核となっ て実施された。通常、3次にわたる調查を実施し、第一次調查はおもにべト ナム側チームが中心に、第二次調查は一部に日本側チームが加わる形で行われ、 さらに第三次では日本側が独自に調查を奏施した。

4 調查が実施された中部・南部の省の民家については、以下の上うな個別の 赧告がなされている。

吉田直子他「ベトナム・フエ省伝統的民家の平面と架構について」日本建策 学会大会学術諈演梗概集 F 2 pp. 181-182 1999 年。䒺田能太郎他「ベトナム・ ドンナイ少伝統的民家の平面と架構について」日本建筑学会大会学術講演梗概
集 F2 pp. 183-184 1999年。チャンティクエハー他「ベトナム・ティエンザン 省の伝綍的民家の調查研究（1）〜 (2)」日本建築学会大会学術講演梗概集 F2 pp.181-1842001 年。高野恵子他「ベトナム・クアンガイ省伝続的民家の平面 と架氉について」日本建築学会大会学術講演梗概集 F2 pp. 184-1852001 年。 チャンティクエハー・山田幸正に゙トトナム・ティンザン省の伝統的民家に関 する研究 $(1) \sim(2) 」 2001$ 年度日本建策学会関東支部研究報告集 pp. 541-548。 中澤寛美他「クアンナム省 DienBan 累 DienPhuong 社の伝統的民家の平面構成

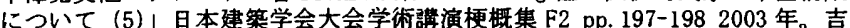
田直子・山田幸正「トゥアティエン・フエ省の伝続的民家」『昭和女子大学国 際文化研究所紀要』Vol5 pp. 22-37 1999 年。崒田龍太郎・山田幸正「ドンナ イ省の伀統的民家」『昭和女子大学国際文化研究所紀要』Vol5 pp. 38-44 1999 年。重枝㤟・中澤宽美「クアンナム省の民家」『昭和女子大学国際文化研究所 紀要』Vol7 pp. 83-1042001 年。高野恵子「クアンガイ省の民家」『昭和女子 大学国際文化研究所紀要』Vol7 pp. 105-125 2001 年。チャンティクエハー・ 山田幸正「ティエンザン省の民家」『昭和女子大学国際文化研究所紀要』Vol7 pp. 127-1432001 年

5 一次調查において、洋風ファサッドで天井をはる例、道に面する町屋風の

例、トラス架構を用いた例あわせて143件は対象外とした。

6 吉田直子他「トウティエンフエ省の伝統的民家」において、「 nhà rường」は 長方形、「nhà rọ」は正方形の平面を持つものとされている。しかし、筆者ら はこれとは別の見解をとる。

7 Pierre - Gourou の研究（文献 6) やNguyễn Khắc Tung の研究（女献 8 ）の ほかにもChu Quang Trứ : KKiến trúc dân gian truyền thống Việt Nam」NXB Mỹ thuật 1996 p.38 などでも同様な㭔称がみられる。

なお、闑き取り調查の対象となったのは、フェ省で 59 件、クアンナム省で 23 件、クアンガイ省で 3 件、ドンナイ省で 23 件、ティエンザン省で 10 件、

である。

8 文献 (6) pp. 44-56

9 文献 (5) p. 802

10 文献 (1) p. 834

11 文献 (4) p. 1187

12 文献 (5) p. 811

13 文献 (1) p. 662

14 文献 (4) p. 1187

15 文献 (5) p. 811

16 クアンガイ省における第一次調查では、型式 1 の事例はみられなかった。 なお、一次調查の写真によって合掌部の納まりを確認できないものは、フエ省 で 11 例中 1 件、ドンナイ省で 180 例中 18 例、ティエンザン省で 168 例中 13 例。

17 文献 (9) (10) を参照。またフエ省の第一次調查で報告されている型式 $1 の 11$ 例は、すべて間口 3 間の家屋で、茅宾きの例も含まれている。クアン ナム省で実测された型式 1 の 2 例はとも間口 5 間であるが、その奥行方向の规 模は南部の民家に比べ、その半分程度しかない（2例の平均値で、間口 12.127 $\mathrm{m} \times$ 奥行 $6.029 \mathrm{~m})$ 。さらに、棟の直下にたつ柱もその高さが $3.700 \mathrm{mほどしか}$ なく、南部民家の平均值 $5.149 \mathrm{~m}$ と比べると、かなり低い棟高であることがわ かる。

18 残り 185 例のうち 168 例は不明で、斜梁が 1 間分の柱間を連結しているこ とが確認できたのは17例のみである。

19 表 2 のうち右端の(6)に示す手法 (棟下にたつ中柱は合䓍よりやや下の位置 で留まり、短い横材を介して斜梁と連結する)は、本稿の考察対象とした中部・ 南部 5 省では見られなかったが、Pierre Gourou（文献6）が指摘したもので、 これを含めて表記した。なお、これまでの調查の中では、北部のなかでも最も 南に位置するゲアン省でこの手法が報告されている。

20 語魚の意味としては「木の莱」を表す。なお、南部 2 省では同様な部材を

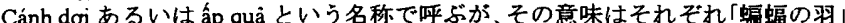
と「果物のへた」で、いずれも三角形をした部材をイメージとして名つけられた と思われる。

21 Nhà trên 「カミヤ、Nhà dưới「シモヤ」。直訳すると前者は「上の家小、後 者は「下の家」となる。文献（9）（10）を参照

22 ドンナイ省 Biên Hoà県 Thống Nhất 村 Võ Văn Danh 宅。中央間は $3,700 \mathrm{~mm}$ 、 左右間はそれぞれ $1,650 \mathrm{~mm}$ と $1,450 \mathrm{~mm}$ である。

23 フエに建設された阮朝の官殿は、規模を別にすれば、建策技法の点では民 家とさほど変らない。これら宫殷建築には、中央柱間の胴差上に束が立つ例が 多くみられる（例えば : Diên Thọ宮, Triệu Miếu, Sùng An 宮, Triệu Tồ Miếu Cần Chánh 殿など)。

24 筆者らのフェ省での調查（第 3 次調查）で、束を立て胴差の下面に天井の ような溥い板を張るものがごく少数例みられた(ベトナム側による第一次調査 にはそうした例は含まれていない)。この板の役割についてはよくわからない が、当然、こうした薄板ではその上に物を収納するための會庫や洪水の避難場 所とすることはできず、胴差上面に張られた厚板とはその目的は異なっている と思われる。

25 洪水時に使う木製の小舟を置いていたという聞き取りがある。 26 フエ省 Hương Thủy 県 Thủy Phù村 Ngô Thi Cháu宅のヨコヤ。中央に柱 4 本 を立て、土間面から $1 \mathrm{~m}$ あまりの高さに横架材を渡し、その上面に床板を張り、 横羽目板壁で囲われ、妻侧に屝口が設けられる。

（2004年 6 月 10 日原稿受理， 2004 年 8 月 12 日採用決定） 